\title{
Principal Component Analysis (PCA) Method for Classification of Beef and Pork Aroma Based on Electronic Nose
}

\author{
Imam Tazi $^{1}$, Nur Laila Isnaini ${ }^{2}$, Mutmainnah $^{3}$, Avin Ainur $^{4}$ \\ ${ }^{1,2,3}$ Department of Physics, Science, and Technology of Faculty, Universitas Islam Negeri Maulana Malik \\ Ibrahim Malang, Gajayana St. No. 50 Malang 65144 \\ ${ }^{4}$ School of Medicine, Faculty of Medicine and Health Science, Universitas Islam Negeri Maulana Malik \\ Ibrahim Malang, Gajayana St. No. 50 Malang 65144 \\ Correspondent email: tazimam1974@gmail.com
}

\begin{abstract}
There are several testing processes for consuming meat products. Organoleptic evaluation is an evaluation based on color, texture, smell, and taste. This research aims to find out the response pattern of 10 gas sensor array contained in the electronic nose against the odor pattern of beef and pork base on a smell. The classification method used is using the Principal Component Analysis (PCA) method. This method is expected to simplify the test of differences in beef and pork based on the aroma. The meat used is standard consumption beef and pork that has been sold in supermarkets. The samples of beef and pork are then ground until smooth. After that, it is weighed for about 1 ounce. The meat samples were tested using an electronic nose consisting of 10 gas sensors. The multivariate analysis method was used to classify the aroma of beef and pork. The results of the data processing showed that the aroma classification of beef and pork which was indexed by the electronic nose was perfect. Based on the PCA method, the proportion of PC1 is 93.4\%, and PC2 is 4.9\%. From the second cumulative number, the value of the first PC was obtained $98.3 \%$. This value indicates that by using only 2-dimensional data, it can represent ten dimensions of data. The loading plot shows that the MQ-138 and MQ-3 sensors are the most powerful sensors in testing samples of beef and pork.
\end{abstract}

Keywords: Array Sensor, Classification, Electronic Nose, PCA.

\section{Introduction}

Humans need protein for the development and regeneration of cells in their needs. Protein has a function to form cells in the body. Protein is an important food source for growth. One source of protein comes from foods that contain meat. Protein from meat can be sourced from beef, goat, pork, and so on. For Muslims consuming pork is prohibited. Pork is very popular in various countries. This pork contains fat that is higher than beef. In Indonesia, the amount of pork is limited and the price is much lower than beef. Therefore, there are some cases of forgery of beef using pork or even beef mixed with pork (Berna, 2010).

Al Qur'an has mentioned 4 times about the prohibition of consuming pork and other meat slaughtered not by the name of Allah SWT. among others in QS. alBaqarah (2): 173, QS. al-Ma'idah (5): 3, QS. al-An'am (6): 145, QS. an-Nahl (16): 115.

There are several methods to test the quality of meat, including chemical testing, physical testing, microbiological testing, and sensory evaluation. Physical examination includes temperature, acidity $(\mathrm{pH})$, water activity, and water binding capacity - testing of light intensity and mechanical tests to determine the texture of meat. The instruments used in the physical analysis were digital thermometers, $\mathrm{pH}$ meters, hygrometers, lux meters, and meat texture measuring instruments (Rudnitskaya \& Legin, 2008; Che Man et al., 2011; Nurjuliana et al., 2011). Based on human sensory organs such as the appearance of flesh, color, texture, smell, and taste. Based on the aroma, fresh meat should smell slightly sour due to the formation of acid, namely lactic acid. Whereas when the flesh decays, it produces an unpleasant odor caused by the degradation of bacteria from meat proteins, such as a mixture of sulfur, mercaptan, etc (Carmel et al., 2003; Arshak et al., 2004; Che Man et al., 2011; Nurjuliana et al., 2011; Falasconi et al., 2012; Jha et al., 2014; Loutfi et al., 2015; Xu et al., 2016).

Electronic Nose is an instrument or measuring device made of chemical sensors combined with a pattern recognition system (Gardner, 1994). The main principle of an electronic nose is to imitate the humans' sense of smelling. The electronic nose receptor consists of several chemical sensors that produce electrical signals. These electrical signals are then analyzed by pattern recognition software. This pattern recognition software is connected with the part of brain 
that can classify and remember smell or aroma ( Penza \& Cassano, 2003; Men et al., 2011; Wilson \& Baietto, 2011; Peng et al., 2014;).

China is one of the largest meat-producing countries in the world. Concerns about food security arose from the rapid growth of the meat industry. They pay more attention to the quality of the meat. The application of conventional test methods for meat quality is limited by many factors, such as longer time to prepare samples and conduct testing. A sensor matrix is built with several gas sensors made for testing. Samples were tested to detect freshness of beef. The results showed that the air sensors of TGS2610, TGS2600, TGS2611, TGS2620 and TGS2602 that were made by Tianjin Figaro Electronic Co., Ltd. could be used to determine the level of freshness. The TGS2442 sensor is not suitable because it has a strong reaction to tainted beef. The relationship between the output of several sensors and the storage time of beef is linear, but the decay of beef cannot be detected clearly (Nurjuliana et al., 2011; Dang et al., 2014; Zhang \& Tian, 2014; Xu et al., 2016).

Principal Component Analysis (PCA) is a method used to reduce the amount of data when a correlation occurs (Tazi et al., 2016; Tazi et al., 2017; Tazi et al., 2018). The aim is to find the base part whose combination is linear with the origin variable which explains each sensor. PCA projects a data matrix that initially has high dimension to the lowest dimension (3 dimensions or 2 dimensions) without losing the required information. The relationship between samples can be visualized by plots of each main component (Li et al., 2007; Peris \& Escuder-gilabert, 2009; Wang et al., 2010; Che Man et al., 2011; Haddi et al., 2011; Nurjuliana et al., 2011; Loutfi et al., 2015; Upadhyay et al., 2017).

From these various backgrounds, researchers wanted to find out the response pattern of an array of 10 gas sensors (electronic nose) to the odor pattern of beef and pork. Data processing method was used to find out its classification using the Principal Component Analysis (PCA) method. The introduction of this pattern is expected to be able to simplify the test of the difference between beef and pork based on the aroma.

\section{Materials and methods}

This research is about the way to classify the aroma of pork and beef. The pattern recognition using the Principal Component Analysis Method is used as an analysis of the smell responses of the electronic nose. The research data collection and processing were carried out at the sensor laboratory of the Department of Physics, Faculty of Science and Technology, State Islamic University of Maulana Malik Ibrahim Malang.

\subsection{Sample preparation}

The samples in this study are beef and pork back part which is regular consumption. Beef is taken from 2 different farms. Pork is also taken from two different farms. The samples are not explicitly treated, for example, being stored in a chamber with a specific gas content. Beef and pork that have been bought weighing 1 ounce are then ground using a blender. Milled meat samples are ready to be used as test samples. The meat is placed in the laboratory with normal air condition. The condition of the air space during data collection is set on uncontrolled room temperature and humidity. This research is about how to classify the aroma of pork and beef. Pattern recognition techniques using the Principal Component Analysis Method are used as an analysis of the smell response of the electronic nose. The research data collection and processing was carried out at the sensor laboratory of the Department of Physics, Faculty of Science and Technology, Universitas Islam Negeri Maulana Malik Ibrahim Malang.

\subsection{Pre-processing and Processing Data}

Data retrieval for each loop is done with a duration of seven minutes. The period of collecting and purging is set to 30 seconds each. The data produce about 840 lines $\mathrm{x} 10$ data sensors. Eight hundred forty data generated by the electronic nose, only the last 600 data were taken. The 600 data consists of 300 data in collecting process and 300 data in purging process. The gas sensor array data generated is dynamic data in the form of collecting and purging data which cannot be directly processed using the statistical method. This is because collecting data and purifying data itself is sinusoidal. The numerical method is used to obtain the sinusoidal area of the data.

\subsection{PCA method processing}

The data acquisition of the odor sensor system consists of 10 gas sensors. Therefore, the data generated is Multivariate data with ten column dimensions. The way to measure the success of this tool is by testing the ability of the device in obtaining meat aroma data then classify it based on the group. The Principal Component Analysis method is perfect for using in processing multivariate data and organizing data distribution. This method creates new data that is built from covariance, eigenvectors, and eigenvalues from the data. PCA groups data covariances by ordering eigenvalues from the highest to the lowest. The covariance value of the data matrix with the highest eigenvalue is covariance data that syncs the entire data with the highest approach. By using PC1 and PC2 data, you can see the 2-dimensional classification of PCA method processing.

\section{Result and discussion}

The sensor arrays used have responded to all compounds that contribute to odor. Each sensor can respond to more than one compound. For example, the MQ-138 gas sensor can sense Aldehyde, Ketone, Alkanoate, Alkanol, Esther, and Ether. Ten sensors have been used in this electronic nose so that they can respond to a variety of different gases. This can 
increase the sensitivity of the device.

\subsection{Score Plot Data}

From Table 1, obtained 2 of the first largest eigenvalue, namely eigen- 1 value $=1.9855$ and eigen2 value $=0.1044$. By using the eigenvalue of each PC, the proportions of each PC can be determined. From the large eigenvalue obtained, the cumulative proportion value of $\mathrm{PC}-1$ is $91.45 \%, \mathrm{PC}-2$ is $6 \%$, and $\mathrm{PC}-3$ is $0.9 \%$.

Loading Plot shows the contribution of all variables used. This study demonstrates the difference in response from all sensors. In Figure 1, the sensor that has a loading plot with the longest positive line is the most critical sensor. The sensor that has the longest positive line is the MQ-2 gas sensor. This sensor has the most significant role or influence in distinguishing samples. The gases that can be responded by MQ- 2 are H2, Volatile Organic Compounds (VOCs / Aldehyde, Ketone, Alkanoate, Alkanol, Esters, Ether), LPG, Propane, Alcohol, Methane, CH4, CO, ISO-Butane. Nine other sensors also continued to contribute when collecting data, but their contribution was smaller.

Table 1 Eigenvalue, Proportion and Cumulative

\begin{tabular}{lll}
\hline Eigenvalue & Proportion & Cumulative (\%) \\
\hline 1.9855 & 0.914 & $91.45 \%$ \\
0.1044 & 0.060 & $97.45 \%$ \\
0.0163 & 0.009 & $98.35 \%$ \\
0.0075 & 0.004 & $99.5 \%$ \\
0.0057 & 0.003 & $99.7 \%$ \\
\hline
\end{tabular}

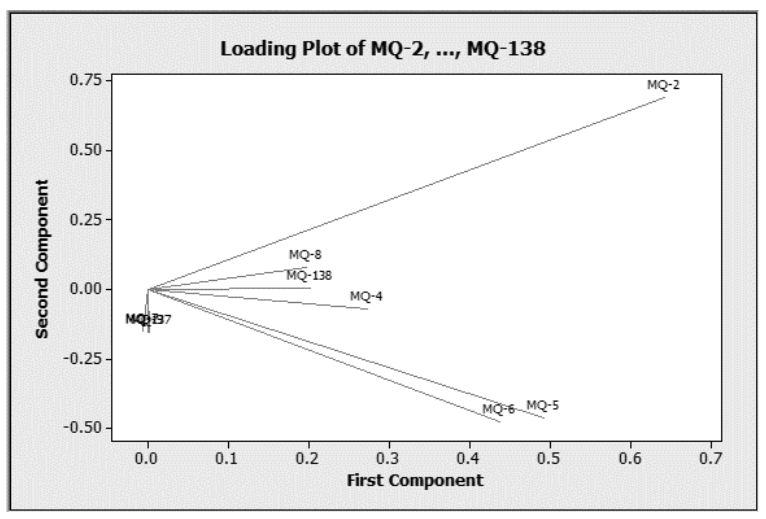

Figure 1. Loading plot of the array sensor

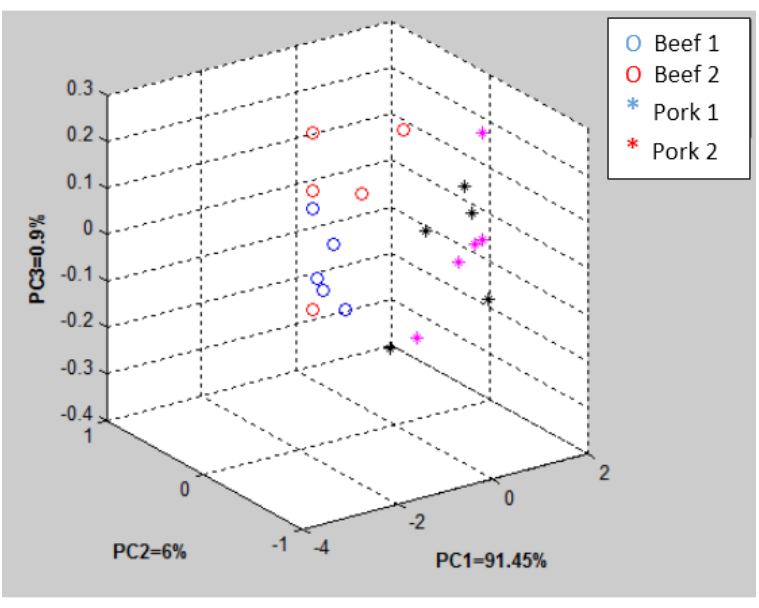

Figure 2. Score Plot of Beef and Pork Meat

The score plot in Figure 2 is used to determine the differences in the schemes of the aroma of beef and pork. The data plot is a 3D plot with coordinates PC1, PC2, and PC3. From the figure, PCA charts are divided into two groups, namely beef, and pork. The roundshaped data points are beef data, and star-shaped ones are pork data.

Figure 2 shows that there are differences in the pattern between the aroma of beef and pork. This can be seen from the separation between the two groups of data. When viewed in each group, 10 points indicate many samples. There are differences in patterns between beef 1 and beef 2 . Likewise with pork 1 and pork 2 . This is because those meats were purchased from 2 different sellers. It is possible that separate animal feed can affect the aroma of the meat.

\section{Conclusion}

Based on the research data, it can be concluded that the electronic nose sensor response can distinguish two groups of beef and pork data. The aroma of beef shows two groups according to the location of purchase, as well as the smell of pork. This is caused by several factors including the types of animals and animal feed. The PCA method gives the results of the first 3 PC cumulative values of $98.35 \%$.

\section{Acknowledgement}

The authors thank Directorate General of Islamic Education. Part of this work was supported financially by the research project of "Penelitian Kompetitif Direktorat Pendidikan Tinggi Islam".

\section{References}

Arshak, K., Moore, E., Lyons, G. M., Harris, J., \& Clifford, S. (2004). A review of gas sensors employed in electronic nose applications, 24(2), 181-198. http://doi.org/10.1108/02602280410525977

Berna, A. (2010). to Food Analysis, 3882-3910. http://doi.org/10.3390/s100403882

Carmel, L., Levy, S., Lancet, D., \& Harel, D. (2003). A feature extraction method for chemical 
sensors in electronic noses, 93, 67-76. http://doi.org/10.1016/S0925-4005(03)00247-8

Che Man, Y. B., Rohman, A., \& Mansor, T. S. T. (2011). Differentiation of lard from other edible fats and oils by means of Fourier transform infrared spectroscopy and chemometrics. JAOCS, Journal of the American Oil Chemists' Society, $\quad 88(2), \quad 187-192$. http://doi.org/10.1007/s11746-010-1659-x

Dang, L., Tian, F., Zhang, L., Kadri, C., \& Yin, X. (2014). Sensors and Actuators A: Physical A novel classifier ensemble for recognition of multiple indoor air contaminants by an electronic nose. Sensors \& Actuators: A. Physical, 207, 67-74. http://doi.org/10.1016/j.sna.2013.12.029

Falasconi, M., Concina, I., Gobbi, E., Sberveglieri, V., Pulvirenti, A., \& Sberveglieri, G. (2012). Electronic Nose for Microbiological Quality Control of Food Products, 2012. http://doi.org/10.1155/2012/715763

Haddi, Z., Amari, A., Ould Ali, A., El Bari, N., Barhoumi, H., Maaref, A., Bouchikhi, B. (2011). Discrimination and identification of geographical origin virgin olive oil by an e-nose based on MOS sensors and pattern recognition techniques. Procedia Engineering, 25, 11371140 . http://doi.org/10.1016/j.proeng.2011.12.280

Jha, S. K., Hayashi, K., \& Yadava, R. D. S. (2014). Neural , fuzzy and neuro-fuzzy approach for concentration estimation of volatile organic compounds by surface acoustic wave sensor array. Measurement, 55, 186-195.

Li, C., Heinemann, P., \& Sherry, R. (2007). Neural network and Bayesian network fusion models to fuse electronic nose and surface acoustic wave sensor data for apple defect detection, 125, 301310. http://doi.org/10.1016/j.snb.2007.02.027

Loutfi, A., Coradeschi, S., Kumar, G., Shankar, P., Bosco, J., \& Rayappan, B. (2015). Electronic noses for food quality: A review. Journal of Food Engineering, 144, 103-111. http://doi.org/10.1016/j.jfoodeng.2014.07.019

Men, H., Liu, H., Pan, Y., Wang, L., \& Zhang, H. (2011). Electronic Nose Based on an Optimized Competition Neural Network, 5005-5019. http://doi.org/10.3390/s110505005

Nurjuliana, M., Che Man, Y. B., \& Mat Hashim, D. (2011). Analysis of lard's aroma by an electronic nose for rapid Halal authentication. JAOCS, Journal of the American Oil Chemists' Society, 88(1), 75-82. http://doi.org/10.1007/s11746010-1655-1

Peng, L., Zou, H., Bauer, R., Liu, Y., Tao, O., Yan, S. Jiang, G. (2014). Identification of Chinese
Herbal Medicines from Zingiberaceae Family Using Feature Extraction and Cascade Classifier Based on Response Signals from E-Nose, 2014.

Penza, M., \& Cassano, G. (2003). Application of principal component analysis and arti $₫$ cial neural networks to recognize the individual VOCs of methanol / 2-propanol in a binary mixture by SAW multi-sensor array, 89, 2-9. http://doi.org/10.1016/S0925-4005(03)00002-9

Peris, M., \& Escuder-gilabert, L. (2009). Analytica Chimica Acta A 21st century technique for food control: Electronic noses, 638, 1-15. http://doi.org/10.1016/j.aca.2009.02.009

Rudnitskaya, A., \& Legin, A. (2008). Sensor systems, electronic tongues and electronic noses, for the monitoring of biotechnological processes, 443451. http://doi.org/10.1007/s10295-007-0298-1

Tazi, I., Choiriyah, A., Siswanta, D., \& Triyana, K. (2017). Detection of Taste Change of Bovine and Goat Milk in Room Ambient Using Electronic Tongue. IJC, 17(3), 422-430.

Tazi, I., Triyana, K., \& Siswanta, D. (2016). A Novel Arduino Mega 2560 Microcontroller-Based Electronic Tongue for Dairy Product Classification. AIP Conference Proceedings, 170003, 21-26.

Tazi, I., Triyana, K., Siswanta, D., Veloso, A. C. A., Peres, A. M., \& Dias, L. G. (2018). Dairy products discrimination according to the milk type using an electrochemical multisensor device coupled with chemometric tools. Journal of Food Measurement and Characterization, $O(0), 0$.

Upadhyay, R., Sehwag, S., \& Mishra, H. N. (2017). Electronic nose guided determination of frying disposal time of sunflower oil using fuzzy logic analysis. Food Chemistry, 221, 379-385. http://doi.org/10.1016/j.foodchem.2016.10.089

Wang, B., Xu, S., \& Sun, D. (2010). Application of the electronic nose to the identification of different milk flavorings. Food Research International, 43(1), 255-262.

Wilson, A. D., \& Baietto, M. (2011). Advances in Electronic-Nose Technologies Developed for Biomedical Applications, 1105-1176. http://doi.org/10.3390/s110101105

Xu, L., Yu, X., Liu, L., \& Zhang, R. (2016). A novel method for qualitative analysis of edible oil oxidation using an electronic nose. Food Chemistry, 202, 229-235. http://doi.org/10.1016/j.foodchem.2016.01.144

Zhang, L., \& Tian, F. (2014). Analytica Chimica Acta A new kernel discriminant analysis framework for electronic nose recognition. Analytica Chimica Acta, 816, 8-17. 